\title{
The Role of Child Sexual Abuse Victims and Pornography as the Etiology of Rape by Male Adolescents in Bengkulu Province, Indonesia
}

\author{
Emi Kosvianti ${ }^{1,2}$, Emy Susanti $^{3}$, Windhu Purnomo ${ }^{4}$, Agung Suhadi ${ }^{5}$ \\ ${ }^{1}$ Doctor Candidate, Faculty of Public Health, Universitas Airlangga, ${ }^{2}$ Lecturer, Department of Public Health, \\ Muhammadiyah University of Bengkulu, ${ }^{3}$ Professor, Department of Sociology, Universitas Airlangga, Indonesia, \\ ${ }^{4}$ Associate Professor, Faculty of Public Health, Universitas Airlangga, Indonesia, ${ }^{5}$ Lecturer in English \\ Departmant, Muhammadiyah University of Bengkulu, Indonesia.
}

\begin{abstract}
Introduction: Rape against adolescent girls, a big crime and unaccaptable whatever its forms because it is a part of human rights violation and a serious problem in reproductive health. For victims, it definitely has profound impact on their long-term life; socially and psychologically as well. Yet, these cases throughout the world increase rapidly and massively, especially in developing countries. This study attempts to investigate the etiology of rape offenders by male adolescents in Bengkulu province, Sumatra, Indonesia.

Method: In this study, the researchers used qualitative method with 29 rape offenders as research informants (they were male adolescents less than 18 years). All informants are being sentenced at the 3 Correctional Institutions and 1 Institute for Special Child Development (LPKA). The data were collected through semistructured interview-a technique for in-depth interview under a guidance of interview guidelines. Thus, the manuscripts of interview will be interpreted and analyzed by interrelated or intercross of sexual violence theory.

Results: The results obtained the otiology of rape offenders by male adolescents less than 18 years are caused by two factors: First, pornography exposure. Informants have been exposed by pornography exposure at various ages, between elementary and high school age. Second, victim of sexual assault. Informants have ever victimized of sexual violence where found that the perpretors are adult people around their life. Some forms of sexual violence, such as seduction urge to visit prostitution location, having free-sex, and watch pornographic contents through internet, gadget, and computer.

Conclusion: In short, this study has set out two important findings; the rape by male adolescents less 18 years are caused by past experiece of sexual assault and the role pornography exposure. Meanwhile, other behaviors allegedly relate to the factors of alcohol consumption and drugs abuse are not discussed in this study.
\end{abstract}

Keywords: Pornoghraphy, child sexual abuse, victim, adolescent, rape.

\section{Introduction}

\section{Corresponding Author:}

\section{Emi Kosvianti}

Doctoral Program, Faculty of Public Health, Universitas Airlangga, Campus C Mulyorejo Surabaya 60115 East Java Indonesia e-mail: emi.kosvianti-2016@fkm.unair.ac.id
Regarding to the rape against adolescents, its impacts and characterisric of perpretors have been observed throughout the word. This crime, according to the some research findings, sexual violence is a part of serious problem that demands massive cost consequences due to the incidence of depression, unwanted pregnancy and the resulting HIV/AIDS ${ }^{[1]}$. Many health problems 
caused by causing sexual violence are not only a concern for criminal law throughout the world but also the field of public health ${ }^{[2]}$. Several studies on sexual violence showed various results regarding the incidence of child sexual violence throughout the world. As reported by a meta-analysis of child sexual violence, from 217 publications as published between 1980 and 2008 which involved 331 independent samples with a total of 9,911,748 participants. Overall, the self-report study an estimated prevalence of child sexual violence was 127/1000, whereas toward participants study a prevalence rate of $4 / 10003$ was obtained [3]. The perpetrators of sexual violence, a group of adolescents age are estimated almost $20-30$ percent of the total sexual crime rate ${ }^{[4]}$. Some previous studies, $1 / 3$ of adolescents who are convicted due to the sexual crimes have repeated their actions. This recidivism violence is a significant problem in the population of perpetrators, especially adolescents who commit various sexual offenses ${ }^{[5]}$.

Related to the sexual aggression, most offenders are often found by adults perpretaors (Mampuru, 2007; Zorn and Noga, 2004). While, it is very rarely found of rape offenders among adults adolescents. Many previous studies link pornography and sexual experiences, with the behavior of rape that has been carried out. Research on informant groups; sexual violations at a young age indicate that exposure to child pornography is described as having an impact on criminal behavior ${ }^{[4]}$. Meanwhile, Burton (2003) described the mechanism of the plausibility relationship between sexual violence behavior and experiences as victims of past sexual crimes, including in terms of modeling the perpetrators by victim. Sexual experience is also thought to be triggered by various factors including experience as a victim varying between $30-50 \%$. This is conditioned as a result of combining several causes of sexual stimulation through sexual violence with signs such as the type of action that appears, and adopting permissive attitudes and beliefs about sex between adults and children ${ }^{[6]}$.

According to our observation, there are many previous studies in term of rape offenders, but there have no study more specific on rape offenders by male adolescents less than 18 years. This study attempts to investigate the child sexual abuse materials as etiology of rape offenders by male adolescents. Therefore, this study investigated the etiology rape offenders by male adolescents at three Bengkulu Correctional Institutions and one Institute for Special Child Development of
Bengkulu province, Indonesia.

\section{Method}

Design and Participants: In this research, the researchers were qualitative method that conducted toward male adolescents less than 18 years, they are all the perpetrators of sexual crime cases, such as rape, copulations with minor, and attempted rape. The informants consisted of 29 adolescents, and are being undergone a sentence at Correctional Institutions. The prospective informants are taken from four institutions of Bengkulu province; 12 informants of Special Child Development Institute (LPKA); 2 informants at Bengkulu Correctional Institution; 13 informants at Correctional Instititution of North Bengkulu, and 2 from South Bengkulu.

Data Collection: Data obtained through semistructured interviews with each participant, which is conducted within six months, from May to October 2019. The interview activity is divided into two sessions; firstly, the interview explores the general information in term of informants' demographic data, such as age, and history of sexual crime cases. Secondly, the session interview to investigate the past history of sexual violence and pornography exposure. Each interview session took between 60 to 90 minutes. With this approach, the informant and interviewer are expected to be able to explore the experience and place it in a context. Moreover, this allows the rape perpetrators to reconstruct in-details of their past experiences. The above, the interview guide is based on the following topics; (1) history of sexual assault cases, (2) experience as a victim of sexual violence, and (3) history of pornography exposure.

Analysis and Interpretation: Data analysis and theoretical interpretation refer to the research problem formulation, namely: (1) how did the informant ever experience sexual violence in the past? (2) what is the history of exposure to research informant pornography? The researcher conducted a thematic analysis of the indepth interview transcript. Furthermore, the researcher interprets the production of the meaning of rape behavior text and compares it with the findings of data from various studies and previous studies.

Ethical Approval and Informed consent: In this research, before and within data collection, have obtained Ethical Clearance, which issued by Health Research Ethics Committee, Nursing Faculty, Airlangga 
University, with ethical approval number 1278-HREC.

Findings: According to our analysis on interview manuscripts, the child victims of sexual violence group are caused by two factors; first, their sexual violence history and pornography exposure experience. All above these upon in-detail are revealed in the following explanation, as follows;

Childhood and Sexual Violence: In term of child victim of sexual assaults, the results of this study revealed that unconciously informants have ever victimized of sexual violence by adults people around them. Informants, as a prepubescent group who were less than 18 years, are mentally influenced by fantasy or sexual desire activities where they actually did not understand at all its hazard impacts on their future life, such as an influencial drive to visit prostitution location, having sex with comercial sex workers, sexual engagement with older couples, and there was persuation and influence to watch pornograpic images or movies; both are free and being asked to pay some money. Thus, this study further explored informants' history as a victim of sexual harrassments, the perpetrators of sexual violence were closest people around their life; they were older people, such as cousins, adopted brothers, friends, adult partners, and commercial sex workers at prostitution location.

The case above as has elaborated from sexual violence lenses, the World Health Organization (WHO) states that sexual violence on child relates to the sexual activity where they do not fully understand and consent [7], developmentally, it is not prepared, violate the law or considered taboo in the social community outlook [8]. In the child group, sexual abuse can be in several forms or activities between children and adults or other children based on age or development in term of responsibility, trust and strength as well. The activities carried out are aimed at satisfying or fulfilling the needs of others, including activities that violate the law, but are not limited to inducement or coercion to a child to have sexual relations, the exploitative use of children in prostitution or other sexual harassment practices, and the exploitative use of children in pornographic performance and material ${ }^{[9]}$.

Some findings of previous researches pointed out the childhood victim experience of sexual violence significantly played a role as deviant predictor of sexual behavior in adult sexual offenders ${ }^{[10]}$. One negative symptom of past traumatic experiences is an increased risk of criminal behavior, including sexual crimes such as rape ${ }^{[11]}$. Significantly, the effect of traumatic experience is more found in men than women ${ }^{[12]}$. Other researches identified the influence of previous trauma exposure, especially strong feelings of fear as triggers of sex offenses namely $85 \%$ of perpetrators ${ }^{[13]}$.

Pornography Exposure Experience: Based on the interview results obtained some information in term of child pornography exposure experience. All informants found that they have accustomed with the exposure of pornography in various ages; between elementary and high school. They admitted to be interested to watch pornography movies and images as well due to some influences of their peers or adults people. The youtube channel is the same as gadget and computer, are often used as media to access pornographic images and movies. Importantly, for schools and home environment, especially private room as a convenient place for child to access pornography movies. Their habits in watching the content of pornography have triggerred their coriousity drive, and want to know about sexual intercourse, so it further encourages them to do rape behavior.

Under article of Law number 44/2008, pornography is a picture, sketch, illustration, photo, text, sound, sound, moving picture, animation, cartoon, conversation, gestures, or other forms of messages through various forms of communication and/or media shows in public, which all contains sexual obscenity or exploitation that violates the norms of decency in society ${ }^{[14]}$. Pornography consumption can give a direct impact, such as addiction, demanding more, ignorance or being insensitive to pornographic content and coveting impingement. While for long term, it can have an impact on the creation of 'Sexually Active Society', which is characterized by a sexually active society (sex desacration or sex is no longer considered a sacred thing), there are no norms that regulate sexual relations and many people live as husband and wife without wedlock, or extramarital relations become unlawful, free-sex have become commonplace ${ }^{[15]}$.

Some tenets of feminists, pornography causes men to rape women ${ }^{[13]}$. This theory is based on three interrelated assumptions, as follows; Sexism and male domination are depicted and celebrated in pornography, which sequentially display images of women as objects of sexual exploitation. Pornography tends to promote and legitimize sexual violence by men. It 
sexually underestimates on women, which requires the fragmentation of a woman's body and eroticization of parts of their body. They argue that pornography demeans and denigrates women, glorifies violence, and legitimizes sexism. MacKinnon argues that sexual objectification is the main root of women's oppression ${ }^{[14]}$.

According to the Cultural Spillover theory (Baron and Straus, 1987), a support for rape may not be limited to the beliefs and attitudes that directly condone sexual violence, for example the myth of rape. There may be other aspects of culture that indirectly function to legitimize rape. This can happen if physical force pattern in one area of life-for example, physical punishment at schools, mass media violence, and the use of government violence must be generalized within relations between the sexes [13], if these cases still happen, violence for non-sexual and socially agreed with the purposes will be associated with the behavior, such as rape.

\section{Conclusion}

This study has set out the findings, some of child rape offending have experienced at childhood violence committed by adults around them. These forms including strong drive to visit and engage sexual activity at prostitution location, and asked to make out and watch pornography as well. The habits of consuming pornography through gadget, internet cafe were found in all informants of rape less than 18 years, which began at various ages; from elementary to senior high age. It is very interesting to be concerned seriously that some places that are often used by children to access pornography content, such as school environment, private room

Implication for Practice and Policy: This finding reinforces our understanding that sexual crime behavior such as rape can be triggered by past traumatic experiences; experiences as victims of sexual violence. Sexual violence can be carried out by close people around child environment such as family and adults people. Therefore, efforts are needed to improve children's acquintance and skills in term of the sexual violence risks, both as victims and perpetrators.

Pornography is often a latent danger whose existence which is not realized by parents. The school and home environment should be a safe place for children, it often turned out to be widely used to access pornography, through gatget and computer. Therefore, good cooperation between parents and schools is needed for preventing and controlling the consumption of pornography among children.

Acknowledgment: The authors would like to say high appreciation to all components, which have supported and participated in conducting this research, especially all informants in Bengkulu Correctional Institutions and Special Child Development Institute. Moreover, a big appreciation to LPDP Scholarship (Indonesian Endowment Fund for Education), Doctorate Program of Public Health Department, Universitas Airlangga, Minister of Law and Human Rights of Indonesia Republic.

\section{Conflict of Interest: Nil}

\section{References}

1. Mathews B, Collin-vézina D. Child sexual abuse: Raising awareness and empathy is essential to promote new public health responses. J Public Health Policy. 2016;37(3):304-14.

2. Bonnar-kidd KK. Sexual Offender Laws and Prevention of Sexual Violence or Recidivism. Vol. 100. 2010. p. 412-9.

3. Stoltenborgh M, Ijzendoorn MH Van, Euser EM, Bakermans-kranenburg MJ. A Global Perspective on Child Sexual Abuse : Meta-Analysis of Prevalence Around the World. Child Maltreat. 2011;16(2):79-101.

4. Sandvik M, Nesset MB, Berg A, Søndenaa E. The Voices of Young Sexual Offenders in Norway : A Qualitative Study. Open J Soc Sci. 2017;5:82-95.

5. Chu CM, Thomas SDM. Adolescent Sexual Offenders : The Relationship Between Typology and Recidivism. Sex Abus A J Res Treat 22(2). 2010;22(2):218-33.

6. Seto MC, Lalumie ML. What Is So Special About Male Adolescent Sexual Offending ? A Review and Test of Explanations Through Meta-Analysis. Psychol Bull. 2010;136(4):526-75.

7. WHO. 7 Child sexual abuse. In: Guidelines for medico-legal care for victims of sexual violence Guidelines for medico-legal care for victims of sexual violence. 2003. p. 75-93.

8. Levenson JS, Grady MD. The Influence of Childhood Trauma on Sexual Violence and Sexual Deviance in Adulthood. Traumatology (Tallahass Fla). 2016;22(2):94-103.

9. Marshall WL. The role of attachments, intimacy, 
and lonliness in the etiology and maintenance of sexual offending. Sex Relatsh Ther. 2017; 1994(November).

10. Edd RAM, Leisen MB, Cusack JF, Ms JL, Ms PL, Mcmackin RA, et al. The Relationship of Trauma Exposure to Sex Offending Behavior Among Male Juvenile Offenders The Relationship of Trauma Exposure to Sex Offending Behavior Among Male Juvenile Offenders. J Child Sex Abus. 2008;8712 (November 2015).

11. Presiden Republik Indonesia. Undang-Undang Republik Indonesia Nomor 44 Tahun 2008 Tentang
Pornografi. 2008.

12. Kementerian Pemberdayaan Perempuan dan Perlindungan Anak Republik Indonesia. Sosialisasi Undang-Undang Republik Indonesia Nomor 4 Tahun 2008. Publikasi dan Media Kementerian Pemberdayaan Perempuan dan Perlindungan Anak Republik Indoensia. 2016.

13. Baron L, Straus MA. Four Theories of Rape: A Macrosociological Analysis. Oxpord J. 1987; 34(5):467-89.

14. Mackinnon CA. Linked references are available on JSTOR for this article : Feminism, Marxism, Method, and the State : An Agenda for Theory. Univ Chicago J. 1982;7(3):515-44. 